and storage iron concentrations in life and between blood ferritin and liver iron concentrations after death. ${ }^{10}$ It is reasonable to suppose that if infants who die of SIDS are born with excess tissue iron stores then this would be reflected in the blood ferritin measured soon after birth.

The availability of blood spots on stored Guthrie cards enabled us to compare blood ferritin concentrations in the first week of life from victims of SIDS and controls. A significant difference might have formed the basis of a useful screening test for infants at risk.

Plasma ferritin concentrations in normal adults vary from 15 to $300 \mu \mathrm{g} / \mathrm{l}$ and reflect the variable concentrations of storage iron present. ${ }^{6}$ There is a similar variability of ferritin concentrations in newborn infants so that wide variations in the mean value of the four control cards for each case are to be expected. The mean value of $93 \mu \mathrm{g} / \mathrm{l}$ in eight samples of cord blood is within the expected range. ${ }^{6}$ In the cord blood samples the plasma component accounts for a mean of $7 \%$ of the total blood ferritin-a smaller proportion than the mean of approximately $20 \%$ for adult blood. ${ }^{10}$

Preliminary studies showed that little ferritin could be extracted from the dried spots of blood on Guthrie cards stored for more than six months. However, with the extraction procedure described above, studies of blood spots stored at temperatures from 4 to $56^{\circ} \mathrm{C}$ indicated that a recovery of about $25 \%$ might be expected for cards stored for prolonged periods of time at room temperature.

Our study is limited by the small numbers and because it would not be possible to detect a difference between a case and the control cards of less than $20 \%$. Nevertheless, there is no evidence from this study that infants who subsequently die of SIDS have elevated blood ferritin concentrations in the first week of life, which would reflect the acquisition of tissue iron in utero.

If infants dying of SIDS have excess iron stores, then this extra iron is the result either of late clamping of the cord which enlarges the red cell mass at birth or to postnatal factors (discussed in ${ }^{5}$ ) which include delayed maturation in replacing haemoglobin $\mathrm{F}$ with haemoglobin A, blood transfusion and iron supplementation.

Further, more detailed, nutritional studies in large populations would be necessary to confirm the suggestion that excess tissue iron is acquired postnatally in victims of SIDS. Both cigarette smoking, which has been consistently associated with SIDS, and high concentrations of tissue iron are known to enhance free radical formation leading to tissue damage. This may prove to be the underlying metabolic explanation for SIDS and deserves further investigation.

We thank the Foundation for the Study of Infant Deaths for financial support, and Drs CM Weaver and Elspeth Webb (Department of Child Health, UWCM) for their help in tracing the cases of SIDS.

1 Gibson AAM. Current epidemiology of SIDS. $f$ Clin Pathol 1992;45:1-10.

2 Oski FA. The erythrocyte and its disorders. In: Nathan DG, Oski FA, eds. Haematology of infancy and childhood. 4th edn. Philadelphia: WB Saunders, 1993:18-43.

3 Lauffer RB. In: Iron and human disease. Boca Raton, Florida: CRC Press, 1992.

4 Berry PJ. Pathological findings in SIDS. $f$ Clin Pathol 1992; 45:11-16.

5 Moore CA, Raha-Chowdhury R, Fagan DG, Worwood M. Liver iron concentrations in sudden infant death syndrome. Arch Dis Child 1994;70:295-8.

6 Worwood M. Serum ferritin. Crit Rev Clin Lab Sci 1979; 10:171-204

7 Cazzola M, Dezza L, Bergamaschi G, Barosi G, Bellotti V, Calder D, et al. Biologic and clinical significance of red cell ferritin. Blood 1983;62:1078-87.

8 Atkinson BG, Dean RL, Tomlinson J, Blaker TW. Rapid purification of ferritin from lysates of red blood cells using proteinase-K. Biochem Cell Biol 1989;67:52-7.

9 Dawson DW, Hoffbrand AV, Worwood M. Investigation of megaloblastic and iron-deficiency anaemias. In: Daciew Sir JV, Lewis SM, eds. Practical haematology. 7th edn. Sir JV, Lewis SM, eds. Practical haematology. 7th

10 Worwood M, Raha-Chowdhury R, Fagan DG, Moore CA. Postmortem blood ferritin concentrations in sudden infant death syndrome. f Clin Pathol 1995;48:763-7.

\title{
Sleeping position and upper airways bacterial flora: relevance to cot death
}

\section{Department of \\ Microbiology, \\ Withington Hospital Manchester M20 8LR $S$ Bell \\ B A Crawley \\ B A Oppenheim \\ Department of Microbiology, Dental School, Manchester University, \\ Manchester M15 6FH \\ D B Drucker \\ Department of Pathology, Royal Lancaster Infirmary, Lancaster LA1 4RP J A Morris \\ Correspondence to: Dr J A Morris. \\ Accepted for publication 5 September 1995}

\author{
S Bell, B A Crawley, B A Oppenheim, D B Drucker, J A Morris
}

\begin{abstract}
The hypothesis that the prone sleeping position is associated with accumulation of upper airways secretions and increased bacterial growth was investigated in adults. Ten subjects with upper respiratory tract infection lay prone for one hour and then supine for one hour. Nasal swabs after the prone period yielded higher bacterial counts than swabs obtained after the supine period. This result could be relevant to sudden infant death syndrome (SIDS), as infants who sleep in the prone position
\end{abstract}

are at increased risk of SIDS and one theory is that death is caused by toxins produced by bacterial overgrowth in the upper respiratory tract following a viral infection.

(F Clin Pathol 1996;49:170-172)

Keywords: upper airways bacterial flora, sleeping position, sudden infant death syndrome.

A number of studies have shown that the prone sleeping position is associated with an increased risk of sudden infant death syndrome (SIDS).$^{1-3}$ 
Bacterial cultures of nasal swabs from 10 adult subjects with upper respiratory infections sampled in the prone and supine positions. Bacterial growth is greater in the prone position (sign test $p<0 \cdot 001$ )

\begin{tabular}{|c|c|c|c|}
\hline \multirow[b]{2}{*}{ Patient no. } & \multirow[b]{2}{*}{ Cultural conditions } & \multicolumn{2}{|c|}{ Number of organisms/ml saline inoculum } \\
\hline & & Prone & Supine \\
\hline 1 & $\begin{array}{l}\text { Anaerobic } \\
\text { Aerobic } \\
\mathrm{CO}_{2}\end{array}$ & $\begin{array}{c}25000 \\
2000 \\
\text { No growth }\end{array}$ & $\begin{array}{c}15000 \\
1000 \\
\text { No growth }\end{array}$ \\
\hline 2 & $\begin{array}{l}\text { Anaerobic } \\
\text { Aerobic } \\
\mathrm{CO}_{2}\end{array}$ & $\begin{array}{c}32000 \\
28000 \\
\text { No growth }\end{array}$ & $\begin{array}{l}\text { No growth } \\
\text { No growth } \\
\text { No growth }\end{array}$ \\
\hline 3 & $\begin{array}{l}\text { Anaerobic } \\
\text { Aerobic } \\
\mathrm{CO}_{2}\end{array}$ & $\begin{array}{l}>100000 \\
>100000 \\
>100000\end{array}$ & $\begin{array}{l}15000 \\
12000 \\
12500\end{array}$ \\
\hline 4 & $\begin{array}{l}\text { Anaerobic } \\
\text { Aerobic } \\
\mathrm{CO}_{2}\end{array}$ & $\begin{array}{l}58000 \\
80000 \\
40000\end{array}$ & $\begin{array}{l}5000 \\
6000 \\
2500\end{array}$ \\
\hline 5 & $\begin{array}{l}\text { Anaerobic } \\
\text { Aerobic } \\
\mathrm{CO}_{2}\end{array}$ & $\begin{array}{l}250000 \\
\text { No growth } \\
250000\end{array}$ & $\begin{array}{l}125000 \\
\text { No growth } \\
125000\end{array}$ \\
\hline 6 & $\begin{array}{l}\text { Anaerobic } \\
\text { Aerobic } \\
\mathrm{CO}_{2}\end{array}$ & $\begin{array}{l}10000 \\
10000 \\
10000\end{array}$ & $\begin{array}{l}\text { No growth } \\
\text { No growth } \\
\text { No growth }\end{array}$ \\
\hline 7 & $\begin{array}{l}\text { Anaerobic } \\
\text { Aerobic } \\
\mathrm{CO}_{2}\end{array}$ & $\begin{array}{l}20000 \\
20000 \\
20000\end{array}$ & $\begin{array}{l}4000 \\
4000 \\
4000\end{array}$ \\
\hline 8 & $\begin{array}{l}\text { Anaerobic } \\
\text { Aerobic } \\
\mathrm{CO}_{2}\end{array}$ & $\begin{array}{c}5000 \\
5000 \\
\text { No growth }\end{array}$ & $\begin{array}{l}\text { No growth } \\
\text { No growth } \\
\text { No growth }\end{array}$ \\
\hline 9 & $\begin{array}{l}\text { Anaerobic } \\
\text { Aerobic } \\
\mathrm{CO}_{2}\end{array}$ & $\begin{array}{l}10000 \\
10000 \\
10000\end{array}$ & $\begin{array}{l}\text { No growth } \\
\text { No growth } \\
\text { No growth }\end{array}$ \\
\hline 10 & $\begin{array}{l}\text { Anaerobic } \\
\text { Aerobic } \\
\mathrm{CO}_{2}\end{array}$ & $\begin{array}{l}50000 \\
50000 \\
50000\end{array}$ & $\begin{array}{l}10000 \\
10000 \\
10000\end{array}$ \\
\hline
\end{tabular}

Furthermore, campaigns to bring this to public attention have led to a reduction in the number of babies sleeping prone and a dramatic reduction in the incidence of SIDS. One explanation for this observation is derived from the hypothesis that SIDS is caused by toxins produced by overgrowth of nasopharyngeal bacteria following a viral infection. ${ }^{4}$ It is suggested that in the prone sleeping position, the clearance of upper respiratory tract secretions is reduced, leading to increased bacterial growth and increased toxin production. ${ }^{5}$ We have investigated this hypothesis in adults.

\section{Methods and results}

Ten adult volunteers, aged from 19 to 35 years, with colds were divided into two groups of five. One group lay prone for one hour and then supine for one hour. The other group lay supine initially for one hour and then prone for one hour. At the end of each period, a swab was passed into the nose and then placed in Stuart's transport medium. The left or the right anterior nares was chosen at random after the first period and the opposite side was sampled after the second period. Each swab was subsequently placed in $5 \mathrm{ml}$ sterile saline and vortexed for one minute. Two blood agar plates and one chocolate agar plate were inoculated using a standard $2 \mu$ l loop of saline suspension and then incubated aerobically (blood agar), anaerobically (blood agar) and in $5 \% \mathrm{CO}_{2}$ (chocolate agar) for 48 hours at $37^{\circ} \mathrm{C}$. Colony counts were performed on the plates and expressed as organisms (strictly colony forming units) per $\mathrm{ml}$ of saline inoculum. The results are shown in the table. In every case the number of organisms was greater in the prone position than in the supine position (sign test $\mathrm{p}<0.001$ ).

\section{Discussion}

The cause of SIDS has not been determined. One hypothesis, however, is that viral respiratory tract infections lead to a disturbance of the upper airways bacterial flora with overgrowth of staphylococci, streptococci and enterobacteria. ${ }^{4-7}$ These organisms produce toxins which might prove fatal in infancy, but only in a narrow time interval between loss of protective maternal IgG and the acquisition of specific immunity. This theory explains the epidemiological features of SIDS, including the association with viral infection, the winter excess and the highly characteristic age incidence curve. A further prediction of this hypothesis is that babies sleeping in the prone position will be at increased risk of SIDS because of pooling of upper airways secretions with increased bacterial carriage and toxin production. This is based on anatomical considerations. Upper airways secretions are normally cleared by the combined effects of gravity and ciliary action into the oesophagus. If ciliary action is impaired by viral infection, the action of gravity becomes more important. The oesophageal inlet is below the upper air passages in the erect position and in the supine position but above them in the prone position.

Ethical considerations preclude the investigation of prone babies, but the work reported here shows clearly that the number of bacteria sampled from the nose is increased in adults with colds who lie prone. This is presumably because the amount of secretion in the nose is increased in this position. A clear difference was obtained after only one hour. It is anticipated that several hours in one position, as occurs in young infants, would lead to an even greater difference as a result of further accumulation of secretions and bacterial growth.

One important anatomical difference between infants and adults is the relative size of the respiratory sinuses. In infants they are small compared with the volume of the anterior and posterior nasal spaces and therefore it is drainage from the latter which is relevant to SIDS. In adults, however, the sinuses are relatively large and drainage from them could contribute to the accumulated secretions in the nasal spaces in the prone position. This does not influence the conclusion that drainage from the nasal spaces is impaired in the prone position compared with the supine position. A number of postulates have been proposed to explain the link between SIDS and the prone sleeping position. These include retention of $\mathrm{CO}_{2}$, positional asphyxia, diminished arousal, and decreased heat loss in the prone position 
increasing the risk of heatstroke. ${ }^{89}$ The explanation proposed here does not preclude these possibilities. Indeed, infection is a major cause of both pyrexia and decreased arousal due to cytokine production. Thus, a number of these factors could act together to bring about a fatal outcome.

1 Fleming PJ, Gilbert R, Azaz Y, Berry PJ, Rudd PT, Stewar $A$, et al. Interaction between bedding and sleeping position in sudden infant death syndrome: a population based case control study. BMF 1990;301:85-9.

2 Engelberts AC, de Jonge GA. Choice of sleeping position for infants: possible association with cot death. Arch Dis Child 1990;65:462-7.
3 Taylor BJ. A review of epidemiological studies of sudden nfant death syndrome in Southern New Zealand. $\mathcal{F}$ Paediat Child Health 1991;27:344-8.

4 Morris JA, Haran D, Smith A. Hypothesis: common bacterial toxins are a possible cause of the sudden infant death syndrome. Med Hypotheses 1987;22:211-22.

5 Morris JA. Sudden infant death syndrome. BMF 1989;298:

6 Telford DR, Morris JA, Hughes P, Conway AR, Lee S, Barson AR, et al. The nasopharyngeal bacterial flora in sudden infant death syndrome. F Infect 1989;18:125-30.

7 McKendrick N, Drucker DB, Morris JA, Telford DR, Barson AJ, Oppenheim BA, et al. Bacterial toxins: a possible cause AJ, Oppenheim BA, et al. Bacterial toxins: a

8 Nelson EAS, Taylor BJ, Weatherall IL. Sleeping position and infant bedding may predispose to hyperthermia and the sudden infant death syndrome. Lancet 1989;i:199-200.

9 Ponsonby A-L, Dwyer T, Gibbons LE, Cochrane JA, Wang Y-G. Factors potentiating the risk of sudden infant death syndrome associated with the prone position. $N \mathrm{Engl} F \mathrm{Med}$ 1993;329:376-82

\title{
Nosocomial empyema caused by Clostridium difficile
}

\author{
A J H Simpson, S S Das, S Tabaqchali
}

\begin{abstract}
Pleural infection with Clostridium difficile is extremely rare. A case of nosocomial empyema following chest drain insertion in a 46 year old man is described. The potential of $C$ difficile to cause extra-intestinal infections should be recognised and its isolation from other sites should not be ignored.
\end{abstract}

(f Clin Pathol 1996;49:172-173)

Keywords: Clostridium difficile, empyema, nosocomial infection.

\section{Case report}

A 46 year old man was transferred from another hospital to St Bartholomew's Hospital, London, with a history of incessant atrial tachycardia secondary to alcoholic cardiomyopathy. Following admission, his tachycardia was treated and stabilised with digoxin $0.25 \mathrm{mg}$ per day and verapamil $80 \mathrm{mg}$ three times daily.

However, an admission chest $x$ ray revealed bilateral pleural effusions, larger on the right. There was increased shadowing and a cavitating mass in the left upper zone, with erosion of the first and second ribs anteriorly, suggestive of malignancy. There was no previous history of tuberculosis. The patient became pyrexial $\left(38^{\circ} \mathrm{C}\right) 24$ hours after admission, and after collection of blood cultures, was started on intravenous cefuroxime $750 \mathrm{mg}$ three times daily and oral erythromycin $500 \mathrm{mg}$ four times daily for a suspected chest infection. He had not previously received any antibiotics. No sputum samples were produced. A diagnostic tap of the right pleural effusion showed pus cells, but no bacteria, and was sterile on culture. A Ziehl-Neelsen (ZN) stain for acid/ alcohol fast bacilli was negative. The protein content was $37 \mathrm{~g} / 1$ and the glucose con- centration $6 \mathrm{mmol} / \mathrm{l}$. Cytology showed abundant polymorphs and reactive mesothelial cells, but no malignant cells. A rapid microagglutination test (RMAT) titre for Legionella pneumophila was less than 1:8.

The patient had a low grade fever over the following week and enlarging pleural effusions. His peripheral white cell count rose from $14.8 \times 10^{9} / 1$ to $19.6 \times 10^{9} / 1$. A pleural biopsy was performed, followed by right chest drain insertion and drainage of $1200 \mathrm{ml}$ blood stained fluid. Routine culture on blood, chocolate and cystine lactose electrolyte difficient (CLED) agar in an aerobic atmosphere with $5 \% \mathrm{CO}_{2}$ at $37^{\circ} \mathrm{C}$, and on blood agar anaerobically $(80 \%$ nitrogen, $10 \%$ hydrogen and $10 \% \mathrm{CO}_{2}$ ) at $37^{\circ} \mathrm{C}$, yielded no growth after 48 hours. $\mathrm{ZN}$ staining was again negative and all cultures for acid fast bacilli were negative at eight weeks. Tuberculin skin testing (1:1000) was negative.

Erythromycin was stopped and intravenous metronidazole added $(500 \mathrm{mg}$ three times daily), in case of aspiration post-cardioversion (attempted before admission to this hospital). Three days later, drainage from the chest drain ceased; a further pleural tap and biopsy was performed, producing thickened blood stained fluid. Cytology showed fibrinous material and many white cells consistent with an empyema. Direct Gram staining showed scanty large Gram positive rods and many neutrophils; anaerobic culture, as described above, revealed a pure growth of Clostridium difficile. Plates incubated aerobically showed no growth. No other specimens processed during this period showed evidence of Gram positive rods on staining, nor was $C$ difficile isolated from any other specimen, suggesting that laboratory contamination was extremely unlikely. The isolate was positive for toxin A using the Premier $C$ difficile Toxin A EIA kit (Meridian Diagnostics 